E3S Web of Conferences 1, 41010 (2013)

DOI: $10.1051 / \mathrm{e} 3$ sconf/ 20130141010

(C) Owned by the authors, published by EDP Sciences, 2014

\title{
Assessing the impacts of gold mining assessing the impacts of gold mining operations on river sediments and water samples from ilesa west local government area ILESA West Local Government Area of Osun State, Nigeria
}

\author{
W. O. Makinde ${ }^{1}$; E. A. Oluyemi ${ }^{2}$ and I.O. Olabanji ${ }^{2}$. \\ ${ }^{1}$ Centre of Energy Research and Development, Obafemi Awolowo University, Ile-Ife. Nigeria \\ ${ }^{2}$ Department of Chemistry, Obafemi Awolowo University, Ile-Ife. Nigeria.
}

\begin{abstract}
Gold mining operations started in the Ilesa-West Local Government Area of Osun state Nigeria in early 1950s. Though official mining operation stopped in mid 1990s, illegal mining is still active in the area till today. Twelve (12) villages were selected for the study based on the high rate of mining activities. The villages are Mokuro, Oke-Ora, Okutu-Omo, Oko Ogboni, Alaba, Itagunmodi, Ariyelepe, Alaba-Oke, Iyere, Igun, Aba-Isobo and Sabo, all in Ilesa South West Local Government area of Osun state, Nigeria within longitude $4^{0} 36^{1}-4^{0} 42^{1} \mathrm{E}$ and latitude $7^{0} 30^{1}-7^{0} 34^{1}$ $\mathrm{N}$. A total of 51 stream water and sediment samples were randomly collected from water sources available to the communities. Stream water samples collected were analyzed for heavy metals using atomic absorption spectrophotometer (AAS) while associated stream sediments were analyzed with $\mathrm{x}$-ray fluorescence spectrometer (XRF). Heavy metals analyzed in both sample types include As, $\mathrm{Cu}, \mathrm{Cd}, \mathrm{Pb}, \mathrm{Fe}, \mathrm{Cr}, \mathrm{Mn}, \mathrm{Zn}, \mathrm{Zr}$, and Sr. Results obtained showed the stream waters to be richly concentrated with toxic metals in the range of $\operatorname{As}(0.002 \pm 0.001$ to $0.004 \pm 0.001 \mathrm{mg} / \mathrm{l}), \mathrm{Cd}$ $(0.003 \pm 0.001$ to $0.034 \pm 0.004 \mathrm{mg} / \mathrm{l}), \mathrm{Pb}(0.002 \pm 0.001$ to $0.017 \pm 0.003 \mathrm{mg} / \mathrm{l}), \mathrm{Cu}(0.078 \pm 0.003$ to $2.326 \pm 0.004 \mathrm{mg} / \mathrm{l}), \mathrm{Zn}(0.013 \pm 0.004$ to $1.937 \pm 0.015 \mathrm{mg} / \mathrm{l}), \mathrm{Fe}(0.013 \pm 0.005$ to $0.825 \pm 0.085 \mathrm{mg} / \mathrm{l})$, $\mathrm{Mn}(0.002 \pm 0.001$ to $0.016 \pm 0.001 \mathrm{mg} / \mathrm{l})$ and $\mathrm{Cr}(0.009 \pm 0.002$ to $0.069 \pm 0.031 \mathrm{mg} / \mathrm{l})$. The variation of heavy metals in stream water samples are $\mathrm{Cu}>\mathrm{Zn}>\mathrm{Cr}>\mathrm{Fe}>\mathrm{Cd}>\mathrm{As}>\mathrm{Pb}>\mathrm{Mn}$. Similar contamination of the stream sediments were observed as XRF results showed the sediments to have high concentration of heavy metals $\mathrm{As}, \mathrm{Cd}, \mathrm{Pb}, \mathrm{Cu}$ and $\mathrm{Cd}$ clearly above regulated limits.

Enrichment Factor of the elements obtained showed high contamination of both the stream water and sediments with toxic metals as a result of high illegal gold mining operations in the area under study.
\end{abstract}

Keywords: Gold, Mining, Heavy Metals, Sediments, Streams. 